\title{
Above-ground biomass models for Seabuckthorn (Hippophae salicifolia) in Mustang District, Nepal
}

\begin{abstract}
R. Rajchal ${ }^{1}$ and H. Meilby ${ }^{2}$
Seabuckthorn (Hippophae salicifolia D. Don.), an important multi-purpose tree, is found at altitudes of 2000-3600 m amsl in Nepal, but so far no models have been developed for estimating the biomass of this species, thus hampering resource assessment and management planning. Hence, the objective of this study was to develop local biomass models for wood, fruit, and leaves of Seabuckthorn. In November 2006, a diameter-stratified sample of 30 trees was harvested in Lete and Kunjo Village Development Committees at an altitude of about $2300 \mathrm{~m}$ amsl in the lower part of Mustang District, Nepal. The fresh weight of fruit and oven-dry weight of wood (stem and branches) and leaves were measured and used as a basis for developing biomass models. Diameters of the trees were measured at $30 \mathrm{~cm}$ above ground whereas the heights were measured in terms of the total tree height $(\mathrm{m})$. Among several models tested, the models suggested for local use were: $\ln ($ woody biomass, oven-dry, $\mathrm{kg})=-3.083+2.436 \ln$ (diameter, $\mathrm{cm}$ ), $\ln$ (fruit biomass, fresh, $\mathrm{kg}$ ) $=-3.237+1.346 \ln$ (diameter, $\mathrm{cm}$ ) and $\ln$ (leaf biomass, oven-dry, kg) $=-4.013+1.403 \ln$ (Diameter, $\mathrm{cm}$ ) with adjusted coefficients of determination of $0.99,0.73$ and 0.91 for wood, fruit, and leaves, respectively. The models suggested for a slightly broader range of environmental conditions were: In (woody biomass, oven-dry, $\mathrm{kg}$ ) $=-3.277+0.924 \ln$ (diameter ${ }^{2} \times$ height), $\ln$ (Fruit biomass, fresh, $\mathrm{kg})=-3.146+0.485 \ln$ (diameter ${ }^{2} \times$ height) and $\ln$ (leaf biomass, oven-dry, kg) $=-4.121+0.532 \ln \left(\right.$ diameter $^{2} \times$ height $)$ with adjusted coefficients of determination of $0.99,0.68$, and 0.92 for wood, fruit, and leaves, respectively. The models can be used in assessment of Seabuckthorn resources and above-ground carbon and in the management of these resources by communities and others.
\end{abstract}

Key words: Allometric models, biomass functions, wood, foliage, fruit, leaves

$\mathrm{S}$ eabuckthorn is a general name for a group of shrubs or small trees belonging to genus Hippophae Linn., under Elaeagnaceae family. All species of the genus Hippophae are dioecious, deciduous, thorny and willow-like woody plants (Lu, 1992). Seabuckthorn is a fast-growing multipurpose species which has an extraordinary capacity to grow and survive under extreme conditions $\left(-40\right.$ to $\left.+40^{\circ} \mathrm{C}\right)$, and has an extensive rooting system with strong soil binding capacity, making the species useful for soil stabilization, river bank control and water retention (TISC, 2001). Seabuckthorn berries and leaves are rich sources of vitamins, antioxidants, and other nutrients and are widely recognized for their medicinal value (Maertz, 2006). For farmers living in the mountains, Seabuckthorn offers opportunities to maintain sustainable livelihoods by providing fuelwood, fodder, healthy foods, and medicinal products and protecting the land from soil erosion (Lu, 1992; Ansari, 2003).

Two species of Hippophae are native to the mountain regions of Nepal, $H$. salicifolia D. Don and H. tibetana Schlecht. (Lu, 1990; Lu, 1992; Kharel, 1999; Vaidya, 1999). According to Gupta et al. (2000), H. salicifolia is found between 2000 $\mathrm{m}$ and $3600 \mathrm{~m}$ altitudes amsl, whereas H. tibetana is found at slightly higher elevations of $3300-$ $4500 \mathrm{~m}$ amsl (Ansari, 2003). The two Hippophae species have been reported from the mountain areas of Baglung, Darchula, Dolakha, Dolpa, Humla, Jajarkot, Jumla, Kaski, Manang, Mugu, Mustang, Ramechhap, Rasuwa, Solukhumbu and Taplejung Districts (Vaidya, 1999; Gupta et al., 2000; TISC, 2001; Baral, 2002). In Mustang District, the species emphasized in this study, $H$. salicifolia, grows along the banks of rivers and

${ }^{1}$ US Geological Survey, Denver, Colorado, USA. E-mail: rrajchal@hotmail.com

${ }^{2}$ Department of Food and Resource Economics, University of Copenhagen, Denmark. 
streams, on flood plains, steep slopes, alluvial soils, and newly eroded colluvial deposits of Lete, Kunjo, and Kobang Village Development Committees (VDCs).

Despite widespread use of Seabuckthorn and considerable worldwide attention, only few studies on the species have been conducted so far in Nepal. Some initiatives have increased local utilization of the fruit of Seabuckthorn by promoting juice making, and it appears that local communities and development organizations are mainly concerned with product utilization issues. However, for commercial utilization and proper management of natural populations of the species, estimation of available resources is crucial. Because of the strong allometric relationship typically observed between biomass and diameter/ height of a tree species, the use of regression estimates offers a reasonable, efficient and nondestructive approach to biomass estimation. Additionally, because of the growing interest in above ground biomass estimation triggered by the need for assessment of carbon stocks in forests, biomass functions for Seabuckthorn offers a useful tool for estimating carbon retention in other similar species for which only few studies have been made.

Therefore, the primary objective of this study was to develop local above ground biomass models for wood, fruit and leaves of Seabuckthorn (H. salicifolia) in Mustang District, Nepal. The study should be useful not only to academic communities for estimating and comparing the biomass of Seabuckthorn forests/thickets but also to the local communities of Mustang District for assessing the current resource status as a basis for planning their resource extraction.

\section{Materials and methods}

\section{Study area}

Mustang is one of the main districts of the Annapurna Conservation Area that covers most of the Annapurna Himal complex and the Kali Gandaki Valley. The district, with Jomsom as its headquarters, covers an area of $3,573 \mathrm{~km}^{2}$, and has a population of about $15,000(\mathrm{HMG} / \mathrm{N}, 2001)$. It extends from $28^{\circ} 24^{\prime}$ to $29^{\circ} 20^{\prime} \mathrm{N}$ latitudes and from $83^{\circ} 30^{\prime}$ to $84^{\circ} 10^{\prime} \mathrm{E}$ longitudes. The terrain is rugged and ranges from $1372 \mathrm{~m}$ to $8167 \mathrm{~m}$ amsl, thus representing sub-tropical to alpine types of climate. The district is characterised by a very large biodiversity, unique landscapes and rich cultural heritage, and has, therefore, become one of the most important tourist destinations in the nation.

The study area is located in Lete and Kunjo VDCs in Lower Mustang, and covers about 61 ha of Seabuckthorn forest/thicket, the majority of which is located along the Kali Gandaki River (Rajchal, 2007) (Fig. 1).

\section{Data collection}

\section{Selection of trees and measurements}

In November 2006, thirty Seabuckthorn trees were selected on the banks of the Kali Gandaki and Lete Rivers, both in Lete and Kunjo VDCs. The trees were evenly distributed across nine diameter classes (each $5 \mathrm{~cm}$ wide); the diameters of the selected sample trees ranged from $1.4 \mathrm{~cm}$ to $43.2 \mathrm{~cm}$ at $30 \mathrm{~cm}$ above ground. The total height of the selected trees ranged from $1.8 \mathrm{~m}$ to $15.2 \mathrm{~m}$. Due to the shrub-like character of $H$. salicifolia and the occurrence of small individuals, the stem diameters were measured $30 \mathrm{~cm}$ above ground. Dead, dying or malformed individuals were avoided while selecting the sample trees. The direction of felling was determined before felling the trees; the ground was cleared for shrubs and other obstacles, and a $20 \mathrm{~m} \times 10 \mathrm{~m}$ Tarpaulin was laid out in the direction of felling to prevent loss of leaves or dead branches. Tree height, crown diameter, bark thickness and number of annual rings $30 \mathrm{~cm}$ above ground were measured after felling. At the analysis stage, these measurements were included in our search for the most suitable biomass model. Tree height and crown diameters were measured to the nearest $10 \mathrm{~cm}$, and diameter $30 \mathrm{~cm}$ above ground was measured to the nearest $1 \mathrm{~mm}$. Finally, the thickness of the bark was measured to the nearest $0.5 \mathrm{~mm}$.

\section{Fresh (green) weight measurement}

The thirty sample trees were cut both at $30 \mathrm{~cm}$ above ground and as close as possible to the ground to include the stump. All branches with leaves and fruit were separated, and the trunk and branches were cut into short, manageable segments. All the leaves were clipped off, and the fruit were collected safely from the branches which were added to the wood biomass. The woody parts were weighed to the nearest $0.1 \mathrm{~kg}$ in the fresh (wet) condition using a Spring Balance, 


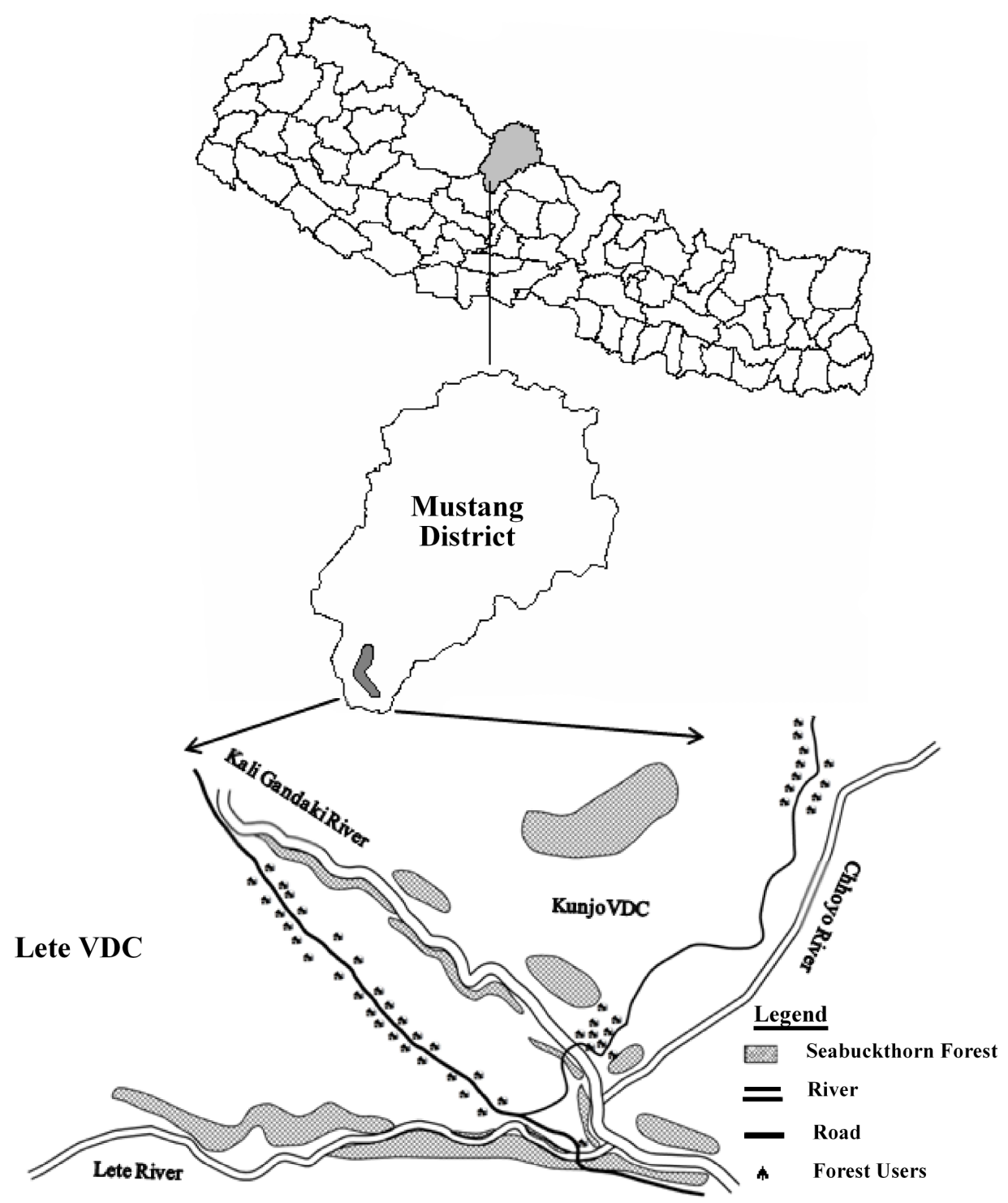

Fig. 1: Map of the study area and the locations of Seabuckthorn (Hippophae salicifolia) forests

and the leaves as well as fruits were weighed in situ to the nearest gram using a battery-powered balance.

\section{Sample collection for oven-dry weight}

Wood discs of stems (approximately 1 inch thick) from different parts of the trees were sawn off in the field, and the fresh weight was determined to the nearest gram using a battery-powered Balance. Representative samples of leaves were collected, and weighed to the nearest gram. Wood and leaf samples were kept in a dry and shady place prior to final oven-drying.

\section{Oven-dry weight determination}

The wood samples were oven dried at a constant temperature of $105^{\circ} \mathrm{C}$ for 48 hours (FRI, 1986) to obtain constant weight (weighing to the nearest
0.01 gram). The leaf samples were oven dried at $70^{\circ} \mathrm{C}$ (Rayachhetry et al., 2001) for 12 hours, until no further weight loss was observed. For each sample, the dry matter content (DMC, in per cent of fresh weight) and the moisture content (MC, in per cent of dry weight) were calculated as:

$D M C=\frac{W_{d r y}}{W_{\text {fresh }}} \times 100 \%$, and $M C=\frac{W_{f r e s h}-W_{d r y}}{W_{d r y}} \times 100 \%$ where, $W_{f r e s h}$ is fresh weight and $W_{d r y}$ is ovendry weight.

Based on these values, average $D M C$ and average moisture content $(M C)$ were estimated for wood and leaves. Using these estimates and the fresh weight measurements made for trunk and branch segments and piles of leaves, oven-dry weights were calculated for each tree for application in 
regression models. For fruit, the fresh weight measured in the field was used directly in regression models.

\section{Biomass models}

A range of different biomass models including some of the models commonly encountered in the literature were tested. The tested models are as follows:

Model 1: $\ln \mathrm{B}=\mathrm{a}+\mathrm{b} \ln \mathrm{D}$

Model 2: $\ln \mathrm{B}=\mathrm{a}+\ln \mathrm{D}^{2} \mathrm{H}$

Model 3: $\ln \mathrm{B}=\mathrm{a}+\mathrm{b} \ln \mathrm{D}+\mathrm{c} \ln \mathrm{H}$

Model 4: $\mathrm{B}=\mathrm{a}+\mathrm{b} \mathrm{D}$

Model 5: $\mathrm{B}=\mathrm{a}+\mathrm{b} \mathrm{H}$

Model 6: $\mathrm{B}=\mathrm{a}+\mathrm{b} \mathrm{D}+\mathrm{c} \mathrm{H}$

Model 7: $\mathrm{B}=\mathrm{a}+\mathrm{b} \mathrm{D}^{2} \mathrm{H}$

Model 8: $\mathrm{B}=\mathrm{a}+\mathrm{b} \mathrm{D}+\mathrm{c} \mathrm{D}^{2}$

Model 9: $\mathrm{B}=\mathrm{a}+\mathrm{b} \mathrm{C}_{\mathrm{d}}$

where, $\mathrm{D}$ is diameter at $30 \mathrm{~cm}, \mathrm{H}$ is total height of the tree, $C_{d}$ is the crown diameter, $B$ is biomass of oven-dry wood, oven-dry leaves, or fresh fruit of Seabuckthorn, and a, b, and c are parameters to be estimated.

Comparison of different models was based on: (i) adjusted coefficient of determination (adj. $\mathrm{R}^{2}$ ) which makes it possible to compare models with different numbers of parameters (Montgomery et al., 2001); (ii) significance of parameter estimates when tested at the $5 \%$ level; (iii) homogeneity of residual variance and distribution of the residuals; (iv) Standard Error of the Estimates or Standard Deviation of the Residuals (SEE); and (v) simplicity and low requirements with respect to number of variables that need to be measured in the field.

Many biomass studies apply data splitting procedures when validating biomass models (e.g. Poudel et al., 2011). However, due to the low number of observations, it would be too wasteful to split the data into separate calibration and validation datasets. Instead, repeated crossvalidation was carried out where, in each of $\mathrm{N}$ validation runs, a single observation was omitted and the model parameters estimated on the remaining N-1 observations. Each of the N resulting models was subsequently used to predict biomass for the tree that was omitted in each of the cases. The errors obtained through this leaveone-out cross-validation were summarised as per centage bias (PBIAS) and root mean squared error per centage (RMSE\%) as follows:

$$
P B I A S=100 \% \times \frac{\sum_{i=1}^{n}\left(B_{o b s, i}-B_{p r e d, i}\right)}{n \overline{B_{o b s}}}
$$

and

$$
R M S E \%=\frac{100 \%}{\overline{B_{o b s}}} \sqrt{\frac{1}{n} \sum_{i=1}^{n}\left(B_{o b s, i}-B_{p r e d, i}\right)^{2}}
$$

where $B_{o b s, i}$ is observed and $B_{\text {pred }, i}$ is predicted biomass and $\mathrm{i}=1 \ldots \mathrm{n}$.

\section{Limitations of the study}

H. salicifolia is a dioecious and biennial plant species and, therefore, only female trees bear fruit and only every second year. Fruit ripening starts in autumn and remain on the branches until the following spring. In this study, only fruiting trees were considered as female, and were, thus, included in the estimation of the biomass model for fruit. Fruits were collected in November during the peak ripening time of the autumn season, and the fruit biomass models, therefore, express the maximum amount of fruit in 2006. H. salicifolia is also a deciduous plant species, and the amount of leaves varies from season to season every year. The plant starts producing leaves in late spring; the leaf biomass reaches maximum during the summer. The leaves begin to fall in the autumn, and completely fall off the branches in the winter. Since sample trees were felled in November, the biomass function for leaves expresses the amount of foliage after the annual peak, but before the minimum was reached.

\section{Results and discussion}

\section{Results}

\section{Basic data}

As described above, average moisture and dry matter contents of wood and leaves were estimated for samples of wood discs and leaves. The estimated average moisture contents of wood and leaves were $137.4 \%$ (SE $1.5 \%, \mathrm{n}=10$ ) and $186.2 \%$ (SE $0.5 \%, \mathrm{n}=5$ ) of dry weight, respectively. The corresponding average dry matter contents of wood and leaves were $42.1 \%$ and $34.9 \%$ of the fresh weight respectively. Based 
on these values and the fresh weights measured in the field, oven-dry weights of wood and leaves were estimated for each sample tree. The entire set of measurements of different variables is presented in table 1.

\section{Development of models}

As expected, the biomass increased with increasing diameter and height. A preliminary examination of scatter plots showing the biomass of wood, fruit, and leaves against diameter and

Table 1. Measurements of biomass components and other variables for 30 individual trees of Seabuckthorn (H. salicifolia D. Don.) sampled in Lete VDC, Mustang District, Nepal in November 2006.

\begin{tabular}{|c|c|c|c|c|c|c|c|c|c|}
\hline \multirow{2}{*}{ SN } & \multirow{2}{*}{$\begin{array}{c}\text { Diameter } \\
\text { at } 30 \mathrm{~cm} \\
(\mathrm{~cm})\end{array}$} & \multirow{2}{*}{$\begin{array}{c}\text { Total } \\
\text { height } \\
\text { (m) }\end{array}$} & \multicolumn{2}{|c|}{$\begin{array}{c}\text { Oven-dry } \\
\text { biomass (kg) }\end{array}$} & \multirow{2}{*}{$\begin{array}{c}\text { Fresh fruit } \\
\text { biomass } \\
\text { (kg) }\end{array}$} & \multirow{2}{*}{$\begin{array}{c}\text { Crown } \\
\text { diameter } \\
(\mathbf{m})\end{array}$} & \multirow{2}{*}{$\begin{array}{c}\text { Bark } \\
\text { thickness } \\
(\mathbf{m m})\end{array}$} & \multirow{2}{*}{$\begin{array}{c}\text { No. of } \\
\text { growth } \\
\text { rings } \dagger\end{array}$} & \multirow{2}{*}{ Sex: } \\
\hline & & & Wood & Leaves & & & & & \\
\hline 1 & 1.4 & 1.8 & 0.18 & 0.03 & 0 & 0.9 & 2 & 2 & $\mathrm{U}$ \\
\hline 2 & 2.5 & 2.2 & 0.67 & 0.06 & 0 & 1 & 2.5 & 3 & $\mathrm{U}$ \\
\hline 3 & 3.4 & 2.6 & 0.46 & 0.12 & 0 & 2.5 & 3 & 4 & $\mathrm{U}$ \\
\hline 4 & 3.5 & 2.6 & 0.55 & 0.14 & 0.16 & 2.7 & 3.2 & 5 & $\mathrm{~F}$ \\
\hline 5 & 4.1 & 3.3 & 1.27 & 0.13 & 0.2 & 1.4 & 3.8 & 5 & $\mathrm{~F}$ \\
\hline 6 & 4.7 & 2.7 & 0.58 & 0.22 & 0.31 & 2.7 & 4 & 5 & $\mathrm{~F}$ \\
\hline 7 & 4.9 & 3.7 & 1.73 & 0.07 & 0 & 1.9 & 4 & 6 & M \\
\hline 8 & 5.2 & 3.5 & 3.58 & 0.23 & 0.96 & 2.1 & 3.8 & 5 & $\mathrm{~F}$ \\
\hline 9 & 6.8 & 3.5 & 6.89 & 0.41 & 1.24 & 2.3 & 3.89 & 5 & $\mathrm{~F}$ \\
\hline 10 & 10.0 & 3.88 & 10.70 & 0.63 & 1.352 & 1.8 & 4.5 & 9 & $\mathrm{~F}$ \\
\hline 11 & 10.0 & 4.9 & 9.14 & 0.24 & 0.668 & 3.55 & 4 & 8 & $\mathrm{~F}$ \\
\hline 12 & 10.8 & 5.3 & 14.61 & 0.33 & 0.095 & 4.15 & 3.5 & 7 & $\mathrm{~F}$ \\
\hline 13 & 12.1 & 8.6 & 22.32 & 0.79 & 0.5 & 3.85 & 6 & 9 & $\mathrm{~F}$ \\
\hline 14 & 12.5 & 5.8 & 21.41 & 0.58 & 0 & 3.8 & 4.37 & 10 & $\mathrm{M}$ \\
\hline 15 & 16.0 & 9.3 & 46.92 & 1.12 & 0.46 & 4.7 & 7.13 & 14 & $\mathrm{~F}$ \\
\hline 16 & 18.8 & 8.7 & 58.60 & 0.13 & 1.08 & 5.6 & 11.5 & 16 & $\mathrm{~F}$ \\
\hline 17 & 19.0 & 6.8 & 62.92 & 0.75 & 3.875 & 5.1 & 10 & 22 & $\mathrm{~F}$ \\
\hline 18 & 20.8 & 8.2 & 71.64 & 0.75 & 2.16 & 5.8 & 13.75 & 30 & $\mathrm{~F}$ \\
\hline 19 & 21.1 & 7.4 & 60.98 & 1.24 & 0.97 & 5 & 7 & 23 & $\mathrm{~F}$ \\
\hline 20 & 26.0 & 9.5 & 113.38 & 0.75 & 3.7 & 4.4 & 8 & 26 & $\mathrm{~F}$ \\
\hline 21 & 26.3 & 9.7 & 141.64 & 1.36 & 3.9 & 5.6 & 9 & 30 & $\mathrm{~F}$ \\
\hline 22 & 26.8 & 9.8 & 164.76 & 1.59 & 3.412 & 8.5 & 14.3 & 33 & $\mathrm{~F}$ \\
\hline 23 & 27.5 & 13.4 & 170.64 & 2.50 & 2.08 & 6.8 & 11.5 & 16 & $\mathrm{~F}$ \\
\hline 24 & 28.9 & 8.0 & 143.93 & 1.22 & 10.26 & 6.75 & 11 & 64 & $\mathrm{~F}$ \\
\hline 25 & 29.0 & 11.5 & 148.18 & 4.06 & 0 & 6.55 & 13.3 & 60 & M \\
\hline 26 & 34.1 & 10.5 & 259.69 & 3.00 & 0 & 7.1 & 13.5 & 44 & M \\
\hline 27 & 35.9 & 11.4 & 280.77 & 2.40 & 5.82 & 8.85 & 15.8 & 51 & $\mathrm{~F}$ \\
\hline 28 & 36.5 & 13.4 & 307.45 & 4.64 & 0 & 8.75 & 12 & 41 & M \\
\hline 29 & 40.1 & 14.0 & 409.72 & 5.10 & 8.51 & 9.05 & 13.5 & 42 & $\mathrm{~F}$ \\
\hline 30 & 43.2 & 15.2 & 528.71 & 5.49 & 6.76 & 9.6 & 14 & 38 & $\mathrm{~F}$ \\
\hline
\end{tabular}

$\uparrow$ Number of growth rings was counted $30 \mathrm{~cm}$ above ground $\$$ Sex: U: Unknown ( $\mathrm{n}=3)$, M: Male $(\mathrm{n}=5), \mathrm{F}$ : Female $(\mathrm{n}=22)$ 
height indicated that relationships between biomass and independent variables were nonlinear and characterised by heterogeneous variance. This is illustrated in figure 2 .
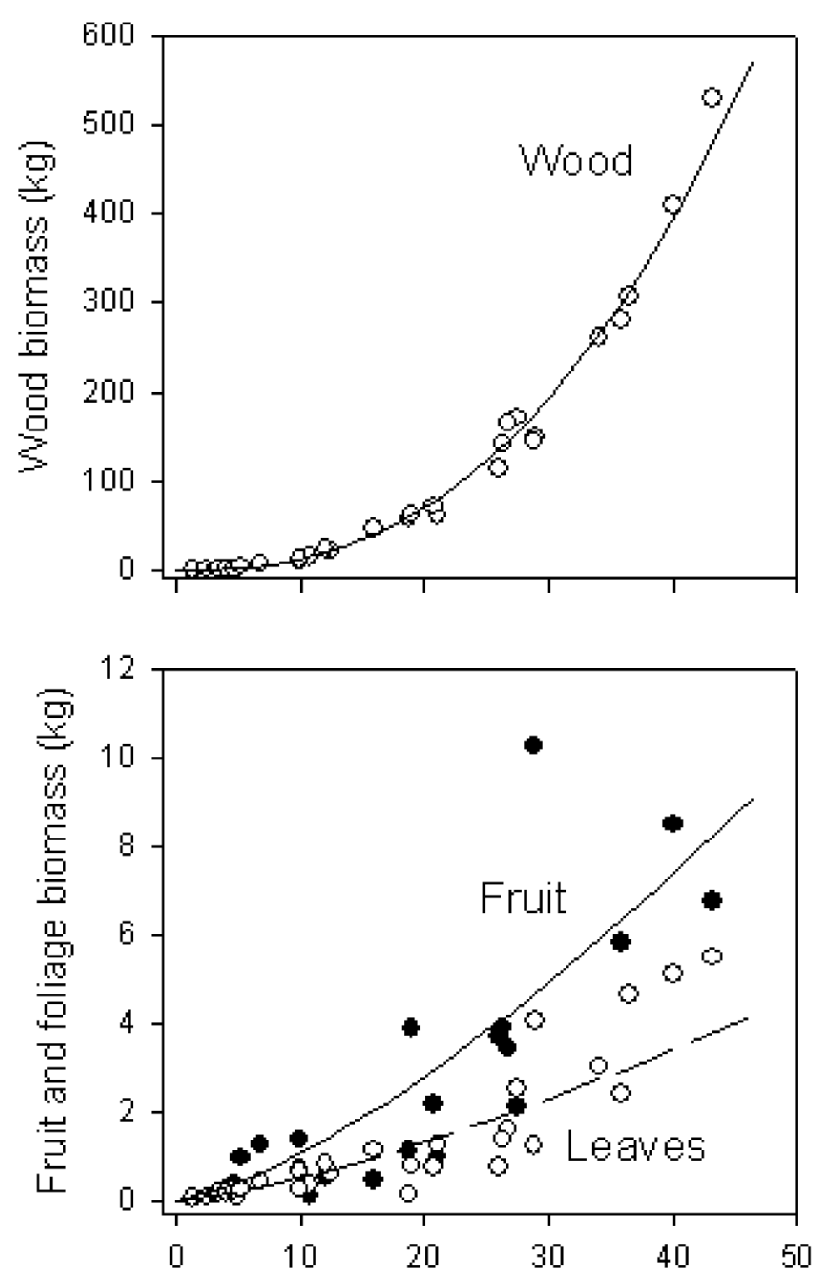

Diameter $30 \mathrm{~cm}$ above ground (cm)
Crown and Schlaegel, 1988; Kadeba, 1991; TerMikaelian and Korzukhin, 1997; Ingerslev and Hallbacken, 1999 and Claesson et al., 2001). Consequently, for the biomass of wood, fruit, and
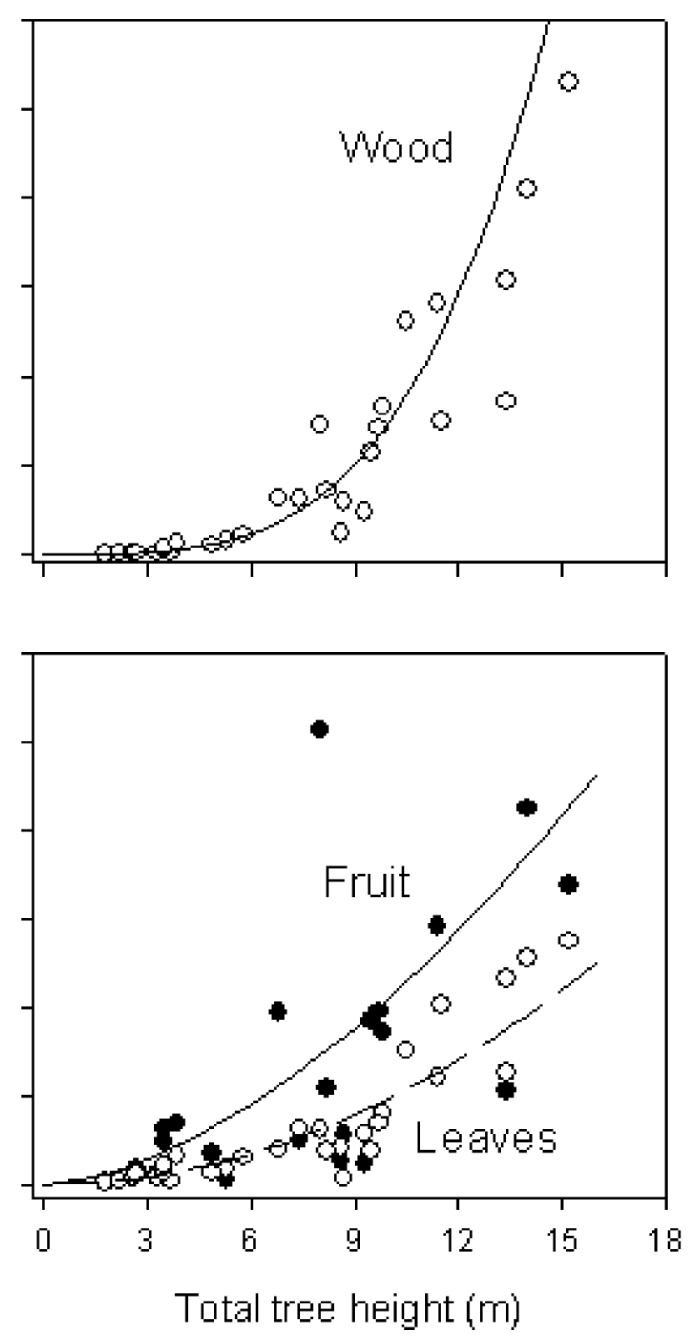

Fig. 2: Biomass of wood, fruit and leaves vs. stem diameter $(30 \mathrm{~cm}$ above ground) and total tree height

Models were developed using stem diameter $30 \mathrm{~cm}$ above ground and total tree height as independent variables. A range of regression models were compared to identify the best possible model for which no deviations from the general assumptions of linear regression were observed and which provided the best possible statistical fit. Among such models, the most attractive relationships between biomass and diameter and/or height was obtained when the logarithm of biomass, $\ln \mathrm{B}$, was regressed against the logarithm of diameter, $\ln \mathrm{D}$ or the product of height and squared diameter, $\ln$ $\mathrm{D}^{2} \mathrm{H}$. Such double-logarithmic allometric models are widely used in tree biomass studies as they generally provide reliable results for many types of biomass measures (Whitesell et al., 1988; leaves, the selected models were:

Model 1: $\quad \ln \mathrm{B}=\mathrm{a}+\mathrm{b} \ln \mathrm{D}$, and

Model 2: $\quad \ln \mathrm{B}=\mathrm{a}+\mathrm{b} \ln \mathrm{D}^{2} \mathrm{H}$

where $\ln$ is the natural logarithm, $\mathrm{B}$ is the biomass, $\mathrm{D}$ is the diameter at $30 \mathrm{~cm}$ above ground, and $\mathrm{H}$ is the total height of the tree.

These models are log-transformed power functions, i.e. $Y=a X^{b}$, but unfortunately, the transformation introduces bias to the estimated biomass (Finney, 1941; Beauchamp and Olson, 1973; Lee, 1982). Sprugel (1983), therefore, proposed a correction factor (CF) which adjusts for the logarithmic bias: 


$$
C F=\exp \left(\frac{S E E^{2}}{2}\right)
$$

For the final selection between the two models, comparisons were made with respect to the significance of the parameters of the regressions, adj. $\mathrm{R}^{2}$, SEE, residual distributions (using scatter plots and histograms), cumulative probability plots and practical applicability of the models. For each of the three biomass components, one major outlier was detected and removed (\#6 for wood, \#12 for fruit and \#16 for leaves, see Table 1) before preparing the final models. Parameter estimates of the models are presented in table 2. Residual plots are shown in figure 3.

All models were highly significant $(\operatorname{Pr}>\mathrm{F}<$ 0.001 ), and except for the fruit biomass models, all adjusted $\mathrm{R}^{2}$ values exceeded 0.8 . In Model 1 , the estimated slope parameter (b) was generally greater than 1, indicating that the biomass of wood, fruit, and leaves all increase progressively with increasing diameter. Furthermore, in agreement with the fact that leaves and fruit are

attached to the same structures of the tree, the estimated slopes of the fruit and leaves biomass functions were similar. For wood and leaves, model 2 yielded a slightly better fit (lower SEE, higher adjusted $\mathrm{R}^{2}$ ) than model 1 , but for fruit, the model fit was not improved by including tree height.

\section{Cross-validation}

The cross-validation showed that both models 1 and 2 for wood and fruit produced small percentage bias values (between $-2 \%$ and $+2 \%$ ), whereas numerically they were slightly larger (about $-6 \%$ ) for leaves (Table 2). In agreement with the patterns observed for SEE and adjusted $\mathrm{R}^{2}$, the root mean squared error percentages for wood and leaves were slightly lower for model 2 than for model 1, whereas the opposite pattern was observed for fruit. Moreover, in agreement with the wide scatter (relative to biomass) observed for fruit and leaves in figure 2, the root mean squared error percentage was much greater $(51-68 \%)$ for fruit and leaves than for wood (14-18\%).

Table 2: Regression models describing above ground biomass components of $\boldsymbol{H}$. salicifolia. Units of measurement: diameter $30 \mathrm{~cm}$ above ground (D): $\mathrm{cm}$, height (H): $\mathrm{m}$, biomass (B): $\mathrm{kg}$.

\begin{tabular}{|c|c|c|c|c|c|c|c|c|c|c|}
\hline \multirow[t]{2}{*}{ SN } & \multirow{2}{*}{$\begin{array}{c}\text { Variable } \\
\text { (biomass) } \\
\text { B }\end{array}$} & \multicolumn{2}{|c|}{$\begin{array}{c}\text { Param. estimates } \\
\text { (and standard } \\
\text { errors) }\end{array}$} & \multirow[t]{2}{*}{ Adj. $R^{2}$} & \multirow[t]{2}{*}{ SEE } & \multirow[t]{2}{*}{$\mathbf{C F}$} & \multirow[t]{2}{*}{ F Value } & \multirow[t]{2}{*}{$\operatorname{Pr}>\mathbf{F}$} & \multicolumn{2}{|c|}{$\begin{array}{l}\text { Leave-one-out } \\
\text { cross-validation } \\
\text { errors }\end{array}$} \\
\hline & & a & b & & & & & & $\begin{array}{c}\text { PBIAS } \dagger \\
\%\end{array}$ & $\begin{array}{c}\text { RMSE: } \\
\%\end{array}$ \\
\hline \multicolumn{11}{|c|}{ Model 1: Models with $\mathrm{D}$ as independent variable $(\ln \mathrm{B}=\mathrm{a}+\mathrm{b} \ln \mathrm{D})$} \\
\hline 1 & Wood (dry) & $\begin{array}{l}-3.083 \\
(0.149)\end{array}$ & $\begin{array}{l}2.436 \\
(0.054)\end{array}$ & 0.986 & 0.269 & 1.037 & 2031.12 & $<0.001$ & -1.61 & 18.17 \\
\hline 2 & Fruit fresh) & $\begin{array}{l}-3.237 \\
(0.512)\end{array}$ & $\begin{array}{l}1.346 \\
(0.181)\end{array}$ & 0.730 & 0.633 & 1.222 & 55.19 & $<0.001$ & 0.18 & 62.09 \\
\hline 3 & $\begin{array}{l}\text { Leaves } \\
\text { (dry) }\end{array}$ & $\begin{array}{l}-4.013 \\
(0.226)\end{array}$ & $\begin{array}{l}1.403 \\
(0.083) \\
\end{array}$ & 0.910 & 0.423 & 1.093 & 282.72 & $<0.001$ & -6.03 & 56.70 \\
\hline \multicolumn{11}{|c|}{ Model 2: Models with $\mathrm{D}^{2} \mathrm{H}$ as independent variable $\left(\ln \mathrm{B}=\mathrm{a}+\mathrm{b} \ln \mathrm{D}^{2} \mathrm{H}\right)$} \\
\hline 1 & Wood (dry) & $\begin{array}{l}-3.277 \\
(0.150)\end{array}$ & $\begin{array}{l}0.924 \\
(0.020)\end{array}$ & 0.987 & 0.264 & 1.036 & 2104.87 & $<0.001$ & 0.89 & 13.68 \\
\hline 2 & $\begin{array}{l}\text { Fruit } \\
\text { (fresh) }\end{array}$ & $\begin{array}{l}-3.146 \\
(0.563)\end{array}$ & $\begin{array}{l}0.485 \\
(0.074)\end{array}$ & 0.679 & 0.690 & 1.269 & 43.36 & $<0.001$ & 1.99 & 68.27 \\
\hline 3 & $\begin{array}{l}\text { Leaves } \\
\text { (dry) }\end{array}$ & $\begin{array}{l}-4.121 \\
(0.224)\end{array}$ & $\begin{array}{l}0.532 \\
(0.031)\end{array}$ & 0.915 & 0.409 & 1.087 & 303.56 & $<0.001$ & -5.57 & 50.95 \\
\hline
\end{tabular}

Note: Number of observations: $\mathrm{n}=29$ for wood and leaves and $\mathrm{n}=21$ for fruit (one outlier omitted in each case)

$\uparrow$ Bias: mean error in per cent of mean biomass

$\$$ Root mean squared error in per cent of mean biomass 

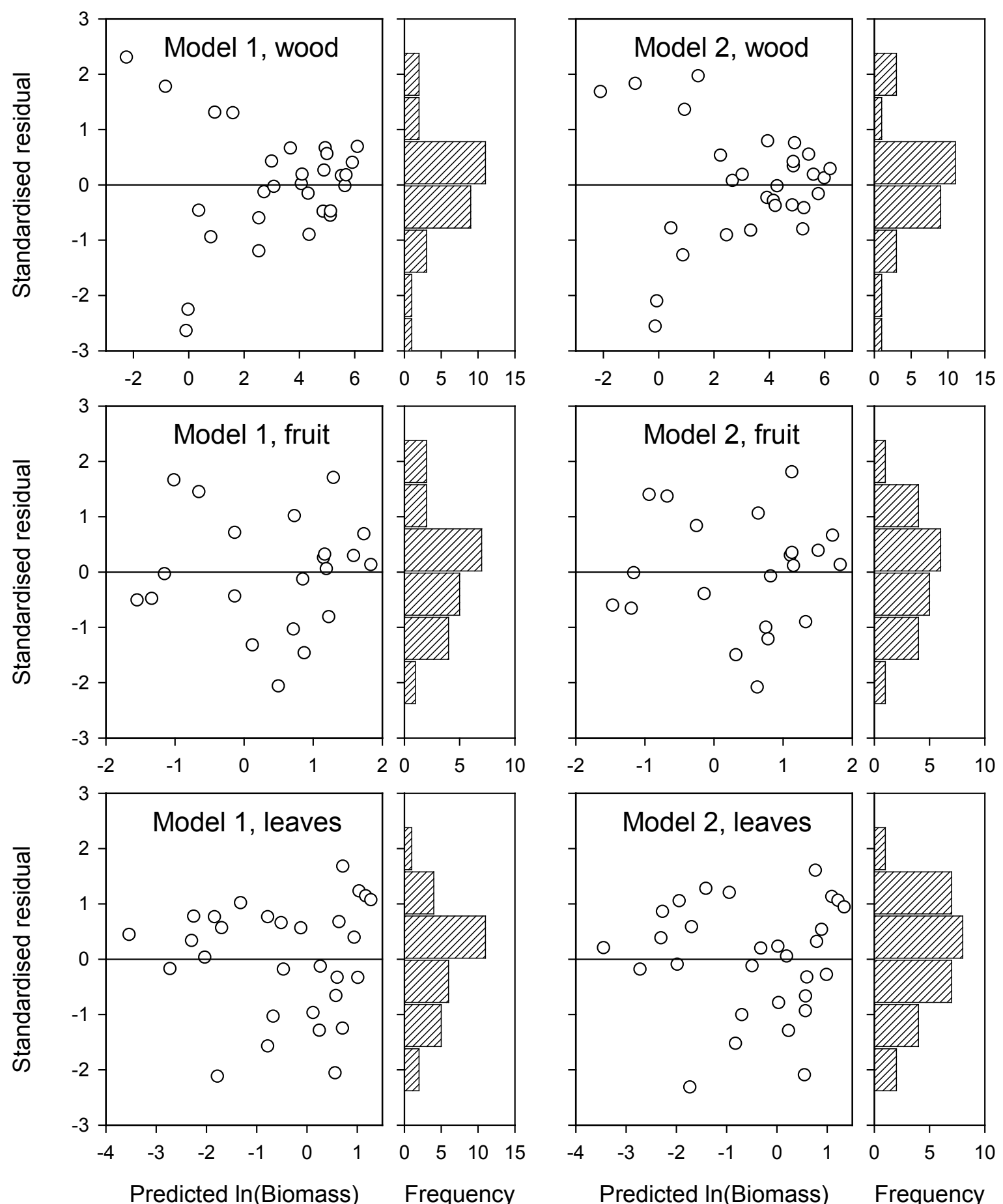

Frequency
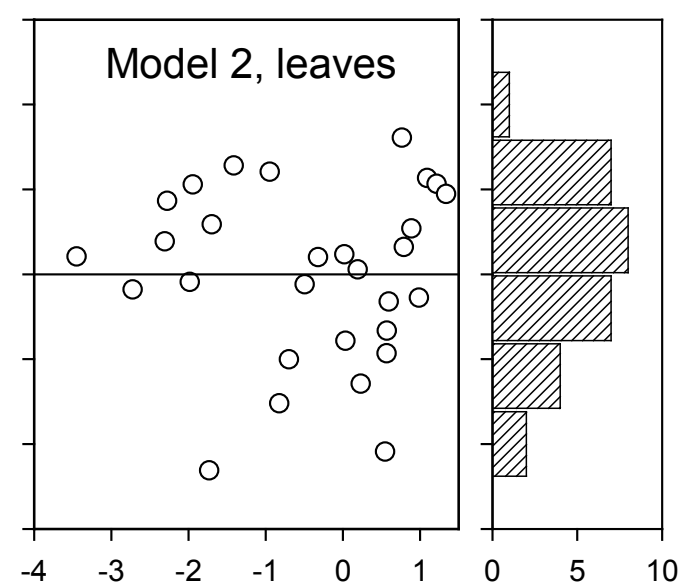

Predicted In(Biomass) Frequency

Fig. 3: Standardized residuals for model 1 (left): In Biomass $=\mathbf{a}+\mathbf{b}$ ln Diameter; and model 2 (right): In Biomass $=a+b$ ln Diameter $^{2} \times$ Height for oven-dry wood (top) and leaves (bottom), and fresh fruit (middle).

\section{Discussion}

\section{Suitability of the models}

Based on the results in table 2, the allometric model $2, \ln \mathrm{B}=\mathrm{a}+\mathrm{b} \ln \mathrm{D}^{2} \mathrm{H}$, seems to be better suited for wood and leaves because the adj. $\mathrm{R}^{2}$ and SEE values are better (higher and lower, respectively) for this model than for the alternative, $\ln \mathrm{B}=\mathrm{a}+\mathrm{b} \ln \mathrm{D}$. Conversely, for fruit, the most attractive model is $\ln \mathrm{B}=\mathrm{a}+\mathrm{b} \ln \mathrm{D}$.

Based on the graphs in figure 3, it appears that for all biomass components, i.e. wood, fruit, and leaves, the standardized residuals of the two alternative models were found to be approximately normally distributed with mean zero. Most standardized 
residuals are small, exhibit no clear pattern and only few values exceed \pm 2 . A visual examination and comparison of the residual plots of the two model types did not reveal any major advantages of one over the other. Line fit plots also showed that the predicted biomass do not deviate much from observed values for any of the biomass components (not shown).

Some Seabuckthorn trees in the study area had lost a major proportion of their branches to firewood, berry and fodder collectors. Others were damaged in other ways. When selecting the 30 sample trees, severely damaged or malformed trees were deliberately avoided, and the models presented here, therefore, describe the expected biomass of trees that are intact or almost intact. When applying the models to populations of trees that have lost part of their crowns, a biomass loss (in terms of percentage) assessment should also be done.

Fruiting presumably varies between years and given the fact that the models presented here are based on data gathered within a single year, observations made in other years may deviate markedly from model predictions. Similarly, it should be noted that the amount of leaves in a given tree varies over the season and from year to year, and leaf biomass models based on data collected in a single year; therefore, the models may not produce central estimates of leaf biomass in other years, or at other times or locations.

\section{Validation of the models}

Due to the low number of observations, creation of separate calibration and validation datasets was considered inappropriate. Instead, leave-oneout cross-validation was carried out, essentially simulating a situation where the final model was applied to a new observation from the same study site. Since no data were available from outside Lete and Kunjo VDCs or from other years than 2006 , it is impossible to state exactly how the models would perform outside this area and year, particularly for fruit and leaves. In agreement with the visual impression (Fig. 2), the cross-validation showed that the validation errors (in per cent) obtained for fruit and leaves varied considerably more than for wood. However, average per centage bias was low for both wood and fruit, but slightly greater for leaves (approx. -6\%). Flowering, fruiting, and foliation are sensitive to time of year, and the current physiological state of the individual fruit is produced only to the extent that resources are available. By contrast, wood biomass is cumulative by nature. Therefore, while the effect of fluctuating growth conditions are smoothened for biomass of wood, the biomass of foliage and particularly fruit vary considerably between individuals of the same size in a given year, as well as between years for a given individual. The relatively poor performance of models for fruit, both in terms of Adj. $\mathrm{R}^{2}$ and $\mathrm{RMSE} \%$, is, therefore, not unexpected.

\section{Applicability of the models}

Both models, $\ln \mathrm{B}=\mathrm{a}+\mathrm{b} \ln \mathrm{D}$ and $\ln \mathrm{B}=\mathrm{a}+\mathrm{b} \ln$ $\mathrm{D}^{2} \mathrm{H}$, are capable of describing the local variation of the biomass of wood, fruit, and leaves. The regression parameters, residual plots and line fit diagrams did not provide any strong arguments for choosing one model over the other. Hence, the following conclusions can be drawn.

For local model application, considering diameter only is a practical solution because including height did not lead to a much better explanation of the variation in biomass. The advantage of a model with diameter as the only independent variable is that it is simple, practical and easy to use (Wang et al., 2000; Ter-Mikaelian and Korzukhin, 1997). The biomass table in annex 1 is, therefore, based on models only including diameter. Several researchers have concluded that tree biomass is primarily a function of diameter (Onyekwelu, 2004; Verwijst and Telenius, 1999; Rapp et al., 1999; Wang et al., 2000; Naidu et al., 1998; Ter-Mikaelian and Korzukhin, 1997; Kadeba, 1991). Furthermore, considering the time that would need to be invested in obtaining height measurements in the field, the associated measurement errors, and the fact that the inclusion of height did not significantly improve the performance of the model, the application of diameter alone is easy to justify.

Growth conditions vary from site to site, and at sites that are poorer or drier than those where the trees were sampled, tree height for a given diameter is likely to be lower than in the dataset used for calibration of the biomass models. Forouhbakhch et al. (2006) showed that the diameter and height are not only good indicators of the site conditions but are also dependent on other factors such as interspecies competition. Feldpausch et al. (2011) stated that the relation between diameter and height varies significantly 
depending on geographical region, climate, forest type and structure. Hence, although the available data did not allow us to validate the models in other areas or for other years, it seems likely that among the two model types presented here, the model type that would be least sensitive to site conditions, and may, therefore, be somewhat safer to use at other sites, is Model 2 with the independent variable $\mathrm{D}^{2} \mathrm{H}$. However, before applying the model, local validation should always be carried out.

\section{Conclusion}

Based on a sample of $30 \mathrm{H}$. salicifolia trees, a range of allometric biomass models were tested, and two models for each biomass component (wood, fruit, and leaves) were proposed, one for local use and another that, after successful validation, may be suitable within a broader range of conditions (Table 2). The entire dataset presented in table 1 should allow future studies to use the dataset for validation of models based on datasets from other stands with $H$. salicifolia. Moreover, future studies may combine the dataset with their own data to prepare models including variation between sites.

\section{Acknowledgments}

This paper is based on part of the first author's M.Sc. thesis. The Community Based Natural Forest and Tree Management in the Himalaya (ComForM) Project and The Rufford Small Grants Foundation provided financial support for the thesis work. We wish to thank Dr. Ram Prasad Sharma from Norwegian University of Life Sciences, Dr. Bimal K. Paudel, Dr. Santosh Rayamajhi, and Prof. Dr. Abhoy K. Das from Institute of Forestry, Pokhara, and Mr. Sanjeev Bhattarai for their academic and practical support. Finally, we would like to express our appreciation to Mr. Bishnu Hari Wagle, Mr. Rabin Kadariya, and all those who assisted the first author in the field.

\section{References}

Ansari, A. S. 2003. "Seabuckthorn (Hippophae spp.) - A Potential Resource for Biodiversity Conservation in Nepal Himalayas" paper presented at International Workshop on Underutilized Plant Species. 06 to 08 May 2003, Leipzig, Germany.

Baral, S. R. 2002. Present status and opportunity of developing Seabuckthorn (Hippophae Linn. spp.) in Nepal: a review. Banko Janakari 12 (2): 33-41.

Beauchamp, J. J. and Olson, J. S. 1973. Corrections for bias in regression estimates after logarithmic transformation. Ecology 54: 1403-1407.

Claesson, S., Sahlen, K. and Lundmark, T. 2001. Functions for biomass estimation of young Pinus sylvestris, Picea abies and Betula spp. from stands in Northern Sweden with high stand densities. Scandinavian Journal of Forest Research 16: 138-146.

Crown, T. R. and Schlaegel, B. E. 1988. A guide to using regression equations for estimating tree biomass. Northern Journal of Applied Forestry 5: 15-22.

Feldpausch, T. R., Banin, L., Phillips, O. L., Baker, T. R., Lewis, S. L. and Quesada, C. A. 2011. Height-diameter allometry of tropical forest trees. Biogeosciences 8: 1081-1106 http://www.biogeosciences.net/8/1081/2011/ bg-8-1081-2011.pdf (Accessed on September 2012).

Finney, D. I. 1941. On the distribution of a variant whose logarithm is normally distributed. Journal of the Royal Statistical Society 7: 155-161.

Forouhbakhch, R., Alvarado-Vazquez, M. A., Hernandez-Pinero, J. L., RochaEstrada, A. and Guzman-Lucio, M. A. 2006. Establishment, growth and biomass production of 10 tree woody species introduced for reforestation and ecological restoration in northeastern Mexico. Forest Ecology and Management 235: 194-201.

FRI, 1986. Indian Forest Utilization. Forest Research Institute and Colleges. Government of India Press, Nasik, India. 1:161-168.

Gupta, V. N., Nepal, V. P., Ghimire, S., Subedi, C. K. and Adhikari, K. 2000. An Ecological Assessment of Seabuckthorn (Hippophae spp.) Resource in North-West Nepal. Tree Improvement and Silviculture Component, Hattisar, Kathmandu, Nepal.

HMG/N. 2001. Population Census 2001. National Planning Commission, Central Bureau of Statistics. His Majesty's Government of Nepal, Kathmandu, Nepal. 
Ingerslev, M. and Hallbacken, L. 1999. Above ground biomass and nutrient distribution in a limed and fertilized Norway Spruce (Picea abies) plantation. Part II. Accumulation of biomass and nutrients. Forest Ecology and Management 199: 21-38.

Kadeba, O. 1991. Above-ground biomass production and nutrient accumulation in an age sequence of Pinus caribaea stands. Forest Ecology and Management 41: 237-248.

Kharel, H. 1999. "Seabuckthorn: A Plant with Great Potential for Remote Areas of Nepal" paper presented at the International Workshop on Seabuckthorn. August 29 - September 2, 1999. Beijing, China. Accessed on www.unv. org.np/RADC/art.htm. 2006/09/01.

Lee, C. Y. 1982. Comparison of two correction methods for the bias due to the logarithmic transformation in the estimation of biomass. Canadian Journal of Forest Research 12: 326-331.

Lu, R. 1990. Seabuckthorn Resouces and its Unexploited Potential in the Himalayan Region. International Center for Integrated Mountain Development (ICIMOD). MFS Series No. 12, Kathmandu, Nepal.

Lu, R. 1992. Seabuckthorn - A Multipurpose Plant for Fragile Mountains. International Center for Integrated Mountain Development (ICIMOD). Occasional Paper No. 20. Kathmandu, Nepal.

Maertz, J. 2006. Seabuckthorn Nutritional Properties: Meet the Little Orange Berry from the Himalayas that's Interesting in Your Well-being. Sibu: The Seabuckthorn Company. Accessed on http://www.mysibu. com. 2006/08/25.

Montgomery, D. C., Peck, E. A. and Vining, G. G. 2001. Introduction to Linear Regression Analysis. Third Edition. Wiley, New York. USA.

Naidu, S. L., DeLucia, E. H. and Thomas, R. B. 1998. Contrasting patterns of biomass allocation in dominant and suppressed Loblolly Pine. Canadian Journal of Forest Research 28: 1116-1124.

Onyekwelu, J. C. 2004. Above ground biomass production and biomass equations for evenaged Gmelina arborea (Roxb.) plantations in South-Western Nigeria. Biomass and Bioenergy 26: 39-46.

Poudel, B. S., Gautam, S. K. and Bhandari, D. N. 2011. Above-ground tree biomass and allometric relationships of Cinnamomum tamala grown in the western hill regions of Nepal. Banko Janakari 21 (1): 3-12.

Rajchal, R. 2007. Biomass Production of Seabuckthorn (Hippophae salicifolia) and its Role in Income Generation. M.Sc. Thesis, Tribhuvan University, Institute of Forestry, Pokhara, Nepal.

Rayachhetry, M. B., Vanb, T. K., Centerb, T. D. and Laroche, F. 2001. Dry weight estimation of the above ground components of Melaleuca quinquenervia trees in Southern Florida. Forest Ecology and Management 142: 281-290.

Rapp, M., Regina, I. S., Rico, M. and Gallego, H. A. 1999. Biomass, nutrient content, litter fall and nutrient return to the soil in Mediterranean Oak forests. Forest Ecology and Management 119: 39-49.

Sprugel, D. G. 1983. Corrections for bias in regression estimates after logarithmic transformation. Ecology 64: 209-210.

Ter-Mikaelian, M. T. and Korzukhin, M. 1997. Biomass equations for sixty-five North American tree species. Forest Ecology and Management 97: 1-24.

TISC. 2001. Proceeding of Workshop on Ecology and Distribution of Seabuckthorn (Hippophae spp.) Resource in Northwest Mountains of Nepal. HMG/DANIDA NARMSAP, Tree Improvement and Silviculture Component, Hattisar, Kathmandu, Nepal.

Vaidya, B. B. 1999. Seabuckthorn Appropriate for Himalayan Region. HMGT/DANIDA, TISC, Kathmandu, Nepal.

Verwijst, T. and Telenius, B. 1999. Biomass estimation procedures in short rotation forestry. Forest Ecology and Management 121: 137-146.

Wang, J. R., Letchford, T., Comeau, P. and Kimmins, J. P. 2000. Above-and belowground biomass and nutrient distribution of a Paper Birch and Subalpine Fir mixed species stand in the sub-boreal Spruce zone of British 
Colombia. Forest Ecology and Management

130: $17-26$.

Whitesell, C. D., Miyasaka, S. C., Strand, R. F.,

Schubert, T. H. and McDuffle, K. E. 1988.

Equations for Predicting Biomass in 2- to

6-year-old Eucalyptus saligna in Hawaii.

USAD Forest. Service Research Notes, PSW-

402.5.

Annex 1. Biomass table for wood (above-ground, dry weight), fruit (fresh weight) and leaves (dry weight) for Seabuckthorn (H. salicifolia D. Don.). model 1, cf. Table 2.

\begin{tabular}{|c|c|c|c|c|c|c|c|}
\hline \multirow[b]{2}{*}{$\begin{array}{l}\text { Diam30 } \\
\text { (cm) }\end{array}$} & \multicolumn{3}{|c|}{ Biomass $\dagger$} & \multicolumn{4}{|c|}{ Biomass $\dagger$} \\
\hline & $\begin{array}{c}\text { Wood } \\
\text { dry (kg) }\end{array}$ & $\begin{array}{c}\text { Fruit } \\
\text { fresh (kg) }\end{array}$ & $\begin{array}{c}\text { Leaves } \\
\text { dry (kg) }\end{array}$ & $\begin{array}{c}\text { Diam30 } \\
\text { (cm) }\end{array}$ & $\begin{array}{c}\text { Wood } \\
\text { dry (kg) }\end{array}$ & $\begin{array}{c}\text { Fruit } \\
\text { fresh (kg) }\end{array}$ & $\begin{array}{c}\text { Leaves } \\
\text { dry (kg) }\end{array}$ \\
\hline 1 & 0.048 & 0.048 & 0.020 & 26 & 132.9 & 3.853 & 1.911 \\
\hline 2 & 0.257 & 0.122 & 0.052 & 27 & 145.7 & 4.053 & 2.015 \\
\hline 3 & 0.690 & 0.211 & 0.092 & 28 & 159.2 & 4.257 & 2.120 \\
\hline 4 & 1.391 & 0.310 & 0.138 & 29 & 173.5 & 4.463 & 2.227 \\
\hline 5 & 2.396 & 0.419 & 0.189 & 30 & 188.4 & 4.671 & 2.336 \\
\hline 6 & 3.736 & 0.535 & 0.244 & 31 & 204.1 & 4.882 & 2.446 \\
\hline 7 & 5.438 & 0.659 & 0.303 & 32 & 220.5 & 5.095 & 2.557 \\
\hline 8 & 7.529 & 0.788 & 0.366 & 33 & 237.6 & 5.310 & 2.670 \\
\hline 9 & 10.03 & 0.924 & 0.431 & 34 & 255.5 & 5.528 & 2.784 \\
\hline 10 & 12.97 & 1.065 & 0.500 & 35 & 274.2 & 5.748 & 2.900 \\
\hline 11 & 16.35 & 1.210 & 0.572 & 36 & 293.7 & 5.970 & 3.017 \\
\hline 12 & 20.21 & 1.361 & 0.646 & 37 & 314.0 & 6.194 & 3.135 \\
\hline 13 & 24.57 & 1.516 & 0.723 & 38 & 335.1 & 6.421 & 3.254 \\
\hline 14 & 29.43 & 1.675 & 0.802 & 39 & 357.0 & 6.649 & 3.375 \\
\hline 15 & 34.81 & 1.837 & 0.883 & 40 & 379.7 & 6.880 & 3.497 \\
\hline 16 & 40.74 & 2.004 & 0.967 & 41 & 403.2 & 7.112 & 3.620 \\
\hline 17 & 47.22 & 2.175 & 1.053 & 42 & 427.6 & 7.347 & 3.745 \\
\hline 18 & 54.28 & 2.349 & 1.141 & 43 & 452.8 & 7.583 & 3.871 \\
\hline 19 & 61.92 & 2.526 & 1.231 & 44 & 478.9 & 7.821 & 3.998 \\
\hline 20 & 70.16 & 2.706 & 1.322 & 45 & 505.8 & 8.062 & 4.126 \\
\hline 21 & 79.01 & 2.890 & 1.416 & 46 & 533.7 & 8.304 & 4.255 \\
\hline 22 & 88.50 & 3.077 & 1.512 & 47 & 562.4 & 8.548 & 4.385 \\
\hline 23 & 98.62 & 3.267 & 1.609 & 48 & 592.0 & 8.793 & 4.517 \\
\hline 24 & 109.4 & 3.459 & 1.708 & 49 & 622.4 & 9.041 & 4.649 \\
\hline 25 & 120.8 & 3.654 & 1.809 & 50 & 653.8 & 9.290 & 4.783 \\
\hline
\end{tabular}

$\uparrow$ Numbers in italics are outside diameter range of the calibration data

\section{Models:}

Wood: $\ln$ Biomass $=-3.083+2.436 \ln$ Diam30, $\mathrm{SEE}=0.269$, Adj. $\mathrm{R}^{2}=0.986, \mathrm{n}=29$

Fruit: $\ln$ Biomass $=-3.237+1.346 \ln$ Diam30, $\mathrm{SEE}=0.633$, Adj. $\mathrm{R}^{2}=0.730, \mathrm{n}=21$

Leaves: $\ln$ Biomass $=-4.013+1.403 \ln$ Diam30, $\mathrm{SEE}=0.423$, Adj. $\mathrm{R}^{2}=0.910, \mathrm{n}=29$

Calibration data:

Data collected at Kali Ghandaki and Lete Rivers, Lete and Kunjo VDCs (cf. Fig. 1), November 2006.

Range of diameter $30 \mathrm{~cm}$ above ground (Diam30): $1.4-43.2 \mathrm{~cm}$

Range of total tree height: $1.8-15.2 \mathrm{~m}$

Range of wood biomass (dry weight): $0.179-528.7 \mathrm{~kg}$

Range of fruit biomass (fresh weight): $0.095-10.26 \mathrm{~kg}$

Range of leaf biomass (dry weight): $0.0342-5.4929 \mathrm{~kg}$ 